\title{
Increased $T$ cell reactivity to amyloid $\beta$ protein in older humans and patients with Alzheimer disease
}

\author{
Alon Monsonego, Victor Zota, Arnon Karni, Jeffery I. Krieger, Amit Bar-Or, Gal Bitan, \\ Andrew E. Budson, Reisa Sperling, Dennis J. Selkoe, and Howard L. Weiner
}

Center for Neurologic Diseases, Harvard Medical School and Brigham and Women's Hospital, Boston, Massachusetts, USA

\begin{abstract}
Alzheimer disease (AD) is characterized by the progressive deposition of the 42-residue amyloid $\beta$ protein $(A \beta)$ in brain regions serving memory and cognition. In animal models of $A D$, immunization with $A \beta$ results in the clearance of $A \beta$ deposits from the brain. However, a trial of vaccination with synthetic human $A \beta 1-42$ in $A D$ resulted in the development of meningoencephalitis in some patients. We measured cellular immune responses to $A \beta$ in middle-aged and elderly healthy subjects and in patients with $\mathrm{AD}$. A significantly higher proportion of healthy elderly subjects and patients with $\mathrm{AD}$ had strong $\mathrm{A} \beta$-reactive $\mathrm{T}$ cell responses than occurred in middle-aged adults. The immunodominant $A \beta$ epitopes in humans resided in amino acids 16-33. Epitope mapping enabled the identification of MHC/T cell receptor (TCR) contact residues. The occurrence of intrinsic $\mathrm{T}$ cell reactivity to the self-antigen $A \beta$ in humans has implications for the design of $A \beta$ vaccines, may itself be linked to $\mathrm{AD}$ susceptibility and course, and appears to be associated with the aging process.
\end{abstract}

J. Clin. Invest. 112:415-422 (2003). doi:10.1172/JCI200318104.

\section{Introduction}

Alzheimer disease $(\mathrm{AD})$ is the most common form of age-related cognitive failure in humans. It is characterized by the progressive accumulation of the amyloid $\beta$ protein $(A \beta)$ in limbic and association cortices, where some of it precipitates to form a range of amorphous and compacted (fibrillar) extracellular plaques $(1,2)$. These plaques, particularly the more compacted ones, are associated with dystrophic neurites (altered axons and dendrites) (3), activated microglia, and reactive astrocytes. Cleavage of the amyloid precursor protein (APP) by the $\beta$ and $\gamma$ secretases releases both the A $1-40$ and $A \beta 1-42$ peptides, the latter being far more prone to aggregation and induction of neurotoxicity (4).

Inflammation may play an important role in mediating the neuronal and glial alterations that occur in $\mathrm{AD}$. Evidence to date has suggested that this inflammation arises mainly from within the CNS (5-7). However, a recent study showed increased occurrence of $\mathrm{T}$ cells in the brains of patients with $\mathrm{AD}$ as compared with subjects with non-AD degenerative dementias and aged-matched controls (8). The inflammatory

Received for publication February 12, 2003, and accepted in revised form April 29, 2003.

Address correspondence to: Howard L. Weiner, Center for Neurologic Diseases, Harvard Medical School and Brigham and Women's Hospital, 77 Avenue Louis Pasteur, HIM 730, Boston, Massachusetts 02115, USA. Phone: (617) 525-5300; Fax: (617) 525-5252; E-mail: hweiner@rics.bwh.harvard.edu. Conflict of interest: The authors have declared that no conflict of interest exists.

Nonstandard abbreviations used: Alzheimer disease (AD); amyloid $\beta$ protein $(\mathrm{A} \beta)$; $\mathrm{T}$ cell receptor (TCR); amyloid precursor protein (APP); glatiramer acetate (GA); Mini Mental State Exam (MMSE); stimulation index (SI). changes - including microgliosis, astrocytosis, complement activation, cytokine elevation, and acute phase protein changes - are thought to represent, at least in part, a response to the early accumulation of $\mathrm{A} \beta 1-42$ in the brain (9-13).

Although $\mathrm{AD}$ is thus associated with local innate immune responses, the induction of systemic adaptive immune responses to $A \beta$ in mouse models of $A D$ has been found to be beneficial for both the neuropathological and behavioral changes that these mice develop (14-20). However, a human clinical trial in which an $A \beta 1-42$ synthetic peptide was administered parenterally with the adjuvant QS21 to patients with $\mathrm{AD}$ was discontinued when approximately $5 \%$ of 300 treated patients developed what appeared to be a self-limited aseptic meningoencephalitis (21). The cause of this reaction is unknown, but one of the major hypotheses is that an immune reaction to $A \beta$ was responsible (21-24).

Self-reactive $T$ cells of low-to-moderate binding affinity are not necessarily deleted during negative selection in the thymus $(25,26)$, and some autoreactive $T$ cells are positively selected and maintain the normal immune repertoire (27). Although such autoreactive $\mathrm{T}$ cells can mediate autoimmune diseases, they may also play a beneficial physiological role in immune regulation and maintenance of normal tissues (28-33). Furthermore, although the CNS has been described as immunologically privileged, it is now known that activated $\mathrm{T}$ cells can routinely penetrate the CNS (34-36).

Although A $\beta$-reactive $B$ cells were previously observed in patients with $\mathrm{AD}(37)$, the presence of $\mathrm{T}$ cell reactivity to $A \beta$ has not been previously described in patients with $\mathrm{AD}$ or shown to be related to the 
aging process. Because $A \beta$ antigen is progressively deposited in the CNS with age and in $\mathrm{AD}$, we postulated that $T$ cell reactivity to $A \beta$ could either decrease or increase with aging and in patients with $\mathrm{AD}$, depending on whether the peptide was tolerogenic or immunogenic. Furthermore, the nature and magnitude of $T$ cell reactivity to $A \beta$ in humans could have either beneficial or injurious effects for the host and may have important implications for $A \beta$ vaccination strategies in $\mathrm{AD}$. We thus initiated a detailed investigation of $T$ cell responses to $A \beta$ both in healthy young and elderly subjects and in patients with AD.

\section{Methods}

Antigens. A $\beta 1-40$ and $\mathrm{A} \beta 1-42$ synthetic peptides were from Biosource International (Camarillo, California, USA). We examined these peptides for fibril formation in $10 \mathrm{mM}$ sodium phosphate ( $\mathrm{pH} 7.4$ ), using quasielastic light-scattering spectroscopy (38). Fibril formation was measured in three equivalent samples of $10 \mu \mathrm{g} / \mathrm{ml} \mathrm{A} \beta$ for 5 consecutive days. Slight increase in particle size was detected in only one sample after a 1 -day incubation, without a significant change up to day 5. Nested $A \beta$ peptides (A $\beta 1-15, A \beta 4-18, A \beta 7-21$, $\mathrm{A} \beta 10-24, \mathrm{~A} \beta 13-27, \mathrm{~A} \beta 16-30, \mathrm{~A} \beta 19-33, \mathrm{~A} \beta 22-36$, $A \beta 25-39$, and $A \beta 28-42$ ) and alanine/glycine-substituted peptides were synthesized at Biosource International (Hopkinton, Massachusetts, USA). A $\beta$ peptides used for T cell assays were dissolved in DMSO (2 $\mathrm{mg} / \mathrm{ml}$ ). Glatiramer acetate (GA) was obtained at the Brigham and Women's Hospital pharmacy.

Human subjects. Subjects with AD (ages 65-90) were recruited from the Memory Disorders Unit at Brigham and Women's Hospital under an International Review Board-approved human studies protocol. The ages and educational background of the patients with $\mathrm{AD}$ were equivalent to those of the healthy older subjects, who were often the spouses of the patients. The diagnosis of $\mathrm{AD}$ was based on National Institute of Neurological Disorders and Stroke-Alzheimer's Disease and Related Disorders Association (NINDS-ADRDA) criteria (39) and included use of the Mini Mental State Exam (MMSE) (40). Patients with mild-to-moderate AD having MMSE scores between 10 and 24 were selected for this study. Patients with severe AD (MMSE of less than 10) or whose history included a severe head injury, alcoholism, major psychiatric illness, epilepsy, or learning disability were excluded from the study. Overall, 27 adults, 35 older healthy individuals, and 42 patients with $\mathrm{AD}$ were evaluated in the study ( $n=104$ subjects). Split-well culture system for $A \beta$ reactivity. PBMCs were isolated from freshly drawn heparinized whole blood by Ficoll-Paque (Amersham Pharmacia Biotech, Uppsala, Sweden) gradient centrifugation, according to the manufacturer's protocol. Cells were cultured in 30 wells of 96-well round-bottom plates at $2 \times 10^{5}$ cells per well in RPMI medium (containing $2.5 \%$ nonautologous serum, $4 \mathrm{mM}$ L-glutamine, $10 \mathrm{mM}$ HEPES,
$1 \mathrm{mM}$ sodium pyruvate, and $10 \mathrm{mM}$ nonessential amino acids) in the presence of pure human $A \beta$ peptide. At day $5,10 \mathrm{U} / \mathrm{ml}$ of recombinant human IL-2 was added by replacing half of the medium with IL-2-containing medium. On day 7, medium was replaced with IL-2-free medium. On day 10 , half the cells from each well were restimulated with irradiated autologous PBMCs in the presence and absence of $10 \mu \mathrm{g} / \mathrm{ml} \mathrm{A} \beta$ for 48 hours and then pulsed with $\left[{ }^{3} \mathrm{H}\right]$ thymidine for 12 hours. Cells were then harvested and radioactivity was measured (in cpm). The stimulation index (SI) (cpm in the presence of $A \beta$ divided by cpm in the absence of $A \beta$ ) was determined. Positive wells are those with an SI of at least 2.5 and a $\Delta \mathrm{cpm}$ of at least 2,000.

Primary stimulation with $\alpha C D 3 / C D 28$ or GA. For $\alpha \mathrm{CD} 3 / \mathrm{CD} 28$ stimulation, frozen PBMCs $\left(2 \times 10^{5}\right.$ cells per well) were cultured in five wells (U-bottom 96-well plate) in the presence of $1 \mu \mathrm{g} / \mathrm{ml}$ soluble $\alpha \mathrm{CD} 3$ plus $\alpha \mathrm{CD} 28$ and in an additional five wells with cell culture medium alone and pulsed with $\left[{ }^{3} \mathrm{H}\right]$ thymidine on day 2 after stimulation, and incorporation was measured 12 hours later. For GA stimulation, fresh PBMCs were cultured in five wells with $50 \mu \mathrm{g} / \mathrm{ml} \mathrm{GA}$ or cell culture medium alone and pulsed with $\left[{ }^{3} \mathrm{H}\right]$ thymidine on day 6 , and incorporation was measured 12 hours later.

$T$ cell lines, fine specificity, cytokine production, proliferation, and flow cytometry. Positive wells obtained in the split-well assay were restimulated 14 days after their primary stimulation in the presence of autologous PBMCs $\left(2 \times 10^{5}\right.$ cells per well $)$ and $A \beta 1-42$. T cell lines were then supplemented with $10 \mathrm{U} / \mathrm{ml} \mathrm{IL-2}$ after 48 hours and every 2 days thereafter until they were completely resting. T cell proliferation was measured 72 hours after stimulation after 12 hours of incubation with $\left[{ }^{3} \mathrm{H}\right]$ thymidine. Supernatants were collected 48 hours after $\mathrm{T}$ cell stimulation, and antigen-induced cytokine production was measured by sandwich ELISA. Recommended pairs of antibodies (coating and detecting) for IL-10 (R\&D Systems Inc., Minneapolis, Minnesota, USA), INF- $\gamma$ (Endogen, Woburn, Massachusetts, USA), IL-13 (PharMingen, San Diego, California, USA), and TGF- $\beta$ (Promega Corp., Madison, Wisconsin, USA) were used according to the manufacturer's instructions. Surface and intracellular staining was performed on antibody-reactive $\mathrm{T}$ cells after stimulation. All antibodies were purchased from BD Biosciences (San Diego, California, USA), and staining was performed according to the manufacturer's instructions.

\section{Results}

Endogenous $T$ cell responses to $A \beta$ in bumans. $T$ cell responses to $A \beta$ were measured using a split-well assay that has been successful in demonstrating reactivity to self-antigens (41). Table 1 shows an example of the results of a split-well assay performed with PBMCs isolated from a healthy adult using $40 \mu \mathrm{g} / \mathrm{ml}$ $\mathrm{A} \beta 1-42$. In this individual, $13.3 \%$ (4 of 30 ) of the wells 
Table 1

T-cell reactivity to $A \beta$ measured by a split-well assay system

\begin{tabular}{cccccccccccccccc}
\hline Aß1-42 & - & + & SI & - & + & SI & - & + & SI & - & + & SI & - & + & SI \\
cpm & 43,789 & 37,865 & 0.9 & 45,099 & 48,685 & 1.1 & 35,245 & 21,634 & 0.6 & $\mathbf{8 , 7 4 5}$ & $\mathbf{6 9 , 8 2 1}$ & $\mathbf{8 . 0}$ & $\mathbf{4 5 , 7 2 3}$ & $\mathbf{1 4 2 , 8 8 0}$ & $\mathbf{3 . 1}$ \\
& 173,254 & 141,713 & 0.8 & $\mathbf{1 1 , 3 9 2}$ & $\mathbf{8 5 , 2 2 6}$ & $\mathbf{7 . 4}$ & 16,037 & 22,330 & 1.4 & 36,315 & 35,369 & 0.9 & 63,579 & 50,010 & 0.8 \\
& 19,889 & 20,689 & 1.1 & 64,853 & 33,523 & 0.5 & 13,687 & 11,926 & 0.9 & $\mathbf{1 2 , 8 7 1}$ & $\mathbf{5 6 , 1 4 7}$ & $\mathbf{4 . 4}$ & 50,468 & 46,617 & 0.9 \\
& 5,874 & 5,566 & 0.9 & 26,719 & 57,697 & 2.1 & 41,186 & 31,531 & 0.8 & 25,355 & 19,537 & 0.8 & 18,268 & 16,304 & 0.9 \\
& 18,923 & 30,122 & 1.6 & 23,614 & 35,242 & 1.5 & 15,753 & 19,795 & 1.3 & 78,577 & 35,267 & 0.4 & 164,315 & 150,771 & 0.9 \\
& 18,816 & 17,705 & 0.9 & 15,029 & 24,260 & 1.6 & 7,300 & 8,183 & 1.1 & 67,300 & 78,350 & 1.2 & 1,542 & 427 & 0.3
\end{tabular}

PBMCs were isolated from an adult healthy individual and cultured in 30 wells of a 96 -well plate with $40 \mathrm{mg} / \mathrm{ml} \mathrm{A} \beta 1-42$. After 10 days, cells from each well were split and transferred to a new 96-well plate and cultured with irradiated autologous PBMCs in the presence or absence of A $31-42$. After 48 hours the cells were pulsed with $\left[{ }^{3} \mathrm{H}\right]$ thymidine for 12 hours, then harvested, after which cpm was measured. SI was calculated as the cpm in the presence of $A \beta$ divided by the cpm in the absence of $A \beta$. SIs are in bold if $\geq 2.5$ and if the $\Delta c p m$ is $\geq 2000$.

demonstrated $\mathrm{A} \beta$-mediated proliferation, with SIs ranging from 3 to 8 and a $\Delta$ cpm higher than 30,000 . Three wells had an SI of $\leq 0.5$. Split-well assays of PBMCs isolated from this subject were also performed using lower concentrations of $A \beta 1-42(0.1,1$, or $10 \mu \mathrm{g} / \mathrm{ml}$ ), and these yielded $20 \%, 14 \%$, and $20 \%$ positive wells, respectively. At these lower antigen concentrations, similar numbers of positive wells and SIs were obtained, with no wells demonstrating SIs $\leq 0.5$ (data not shown); the latter is possibly secondary to activation-induced $\mathrm{T}$ cell death. Because $\mathrm{A} \beta$-reactive $\mathrm{T}$ cell lines usually proliferated maximally with 10 $\mu \mathrm{g} / \mathrm{ml} \mathrm{A} \beta 1-42$, split-well assays were performed using $10 \mu \mathrm{g} / \mathrm{ml} \mathrm{A} \beta 1-42$ in our subjects.

$A \beta 1-42$ is more immunogenic than $A \beta 1-40$. Before testing large numbers of subjects using the split-well assay, we determined the relative antigenicity of the two major forms of $A \beta, 1-40$ and 1-42. Split-well assays were performed in nine subjects (three young adults, 25-40 years old; three older healthy subjects, 50-85 years old; and three patients with $\mathrm{AD}, 58-90$ years old) using either $A \beta 1-40$ or $A \beta 1-42$. Of these, six subjects (three adults, one older subject, and two patients with $\mathrm{AD}$ ) showed a markedly higher percentage of positive wells when $A \beta 1-42$ was used as the antigen, whereas only three subjects, who had low percentages of positive wells, showed similar or slightly higher reactivity evoked by $\mathrm{A} \beta 1-40$ (Figure 1 ). On the basis of these results, we chose to measure $T$ cell responses to $A \beta 1-42$ exclusively.

Increased $T$ cell reactivity to $A \beta$ in elderly subjects and patients with $A D$. As described above (Figure 1), we found evidence of $T$ cell reactivity to $A \beta$ in patients with $\mathrm{AD}$ and healthy adult and elderly subjects. To address the relative responses to $A \beta 1-42$ among these three groups, we performed split-well assays on PBMCs derived from young adults (25-40 years old, $n=13$ ), older healthy subjects ( $50-85$ years old, $n=22$ ), and patients with $\mathrm{AD}(58-90$ years old, $n=29)$, using $\mathrm{A} \beta 1-42(10 \mu \mathrm{g} / \mathrm{ml})$ as the stimulating antigen. The percentage of positive $T$ cell reactivity to $A \beta 1-42$ (as defined by an SI of at least 2.5 and a $\Delta c p m$ of at least $2,000)$ was significantly higher in healthy elderly subjects (mean, 27\%) than in normal adult subjects (mean, 14\%) $(P=0.05)$ (Figure 2a). Regression analy- sis demonstrated a trend linking increased $\mathrm{T}$ cell reactivity with age $(r=0.29, P=0.09)$. In addition, a significantly higher average of percent positive wells (29\%) was also observed in the group of patients with $\mathrm{AD}$ (different from adults at $P=0.01$ ), whereas the elderly group did not differ from the $\mathrm{AD}$ group (Figure 2a). Furthermore, several of the elderly healthy subjects and the patients with $\mathrm{AD}$ had a markedly elevated percentage of positive wells (over 50\%) (Figure 2a). Although the difference between the mean reactivities of the patients with $\mathrm{AD}$ and the elderly subjects was not significant, $23 \%$ (5 of 22) of the elderly subjects had no $T$ cell reactivity to $A \beta$, whereas this was not observed in patients with $\mathrm{AD}(0$ of 29$)(P=0.03)$.

Although the percent positive wells provide a measure of reactivity to $A \beta$, they do not assess the

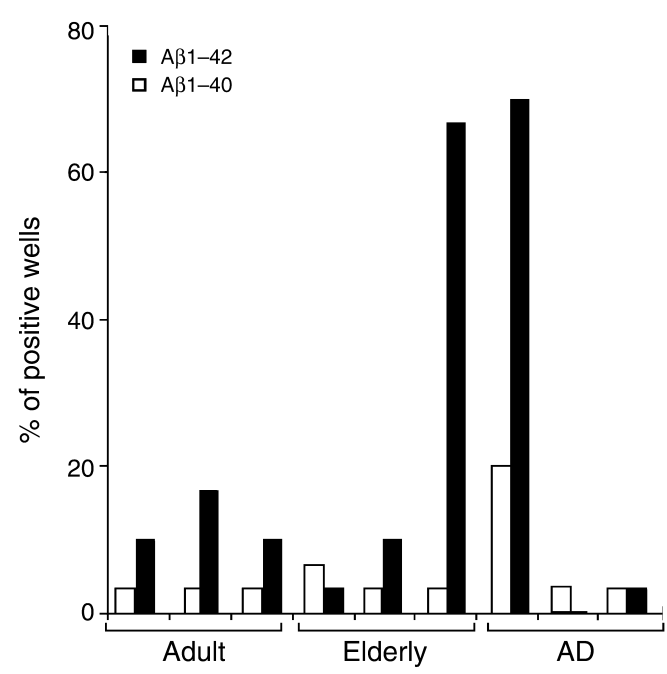

Figure 1

$A \beta 1-42$ is more immunogenic than $A \beta 1-40$. PBMCs were isolated from nine subjects (three adults, three older healthy subjects, and three patients with clinically mild or moderate $A D$ ) and cultured in U-bottom 96-well plates in the presence of human $A \beta 1-40$ or $A \beta 1-42$ (30 wells per peptide) as described in Methods. Cells were then restimulated at day 10 in the presence or absence of the peptide used initially. T cell proliferation was measured by $\left[{ }^{3} \mathrm{H}\right]$ thymidine incorporation 72 hours after the secondary stimulation. The percentage of positive wells was obtained according to the number of wells (out of 30 ) with SIs (cpm in the presence of antigen divided by cpm in the absence of antigen) of at least 2.5 and a $\Delta \mathrm{cpm}$ of at least 2,000. 

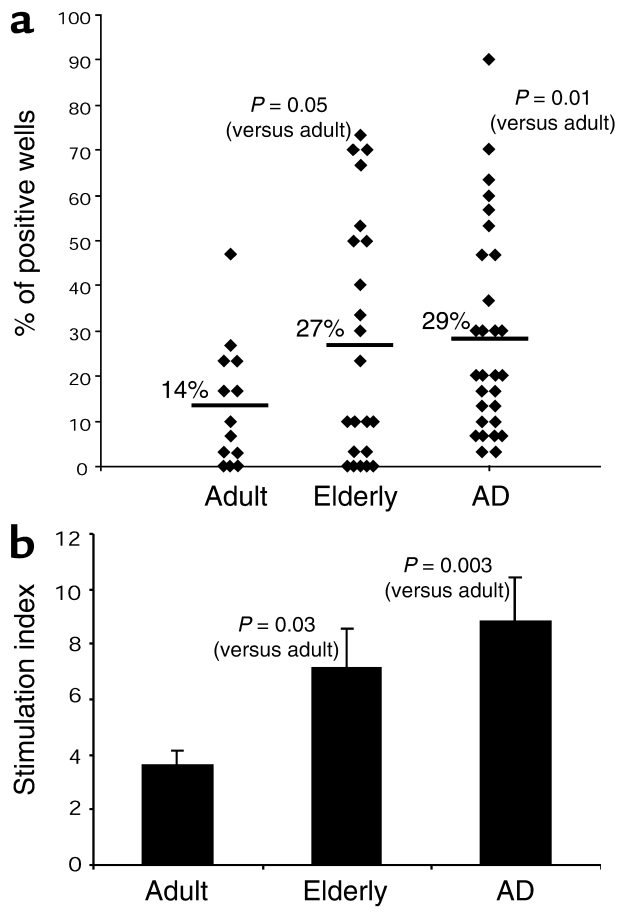

magnitude of the response. Accordingly, to determine whether the strength of the response to $A \beta$ as measured by mean SIs was also higher in the elderly subjects and patients with $\mathrm{AD}$, average SIs were calculated from the positive wells of each of the subjects tested. We found that average SIs were significantly higher in the healthy elderly and AD groups than in the adult group $(P=0.03$ and 0.003 , respectively) (Figure 2b).

The increased reactivity to $A \beta$ was significant, given that $T$ cell immunity tends to decrease with aging (42, 43), since older humans are more susceptible to infectious diseases and the effects of vaccination are reduced in the elderly (44). To determine whether the increased $A \beta$ responses seen in our elderly and $A D$ groups were also observed for other $T$ cell responses, we examined $T$ cell responses to $\alpha \mathrm{CD} 3 / \mathrm{CD} 28$ antibodies and to a universal antigen that stimulates $T$ cells through the $T$ cell receptor (TCR), GA (45). GA is a synthetic random polypeptide that stimulates a broad spectrum of HLA class II-restricted $\mathrm{CD}^{+} \mathrm{T}$ cell populations in human PBMCs (46), and $\mathrm{T}$ cell reactivity to GA in humans does not require prior in vivo priming. Thus, $\alpha \mathrm{CD} 3 / \mathrm{CD} 28$ stimulation and primary $\mathrm{T}$ cell responses to $\mathrm{GA}$ were measured as an indication of global $\mathrm{T}$ cell activation and proliferation. As shown in Table 2, proliferative responses to $\alpha \mathrm{CD} 3 / \mathrm{CD} 28$ or GA were not increased in the elderly or in patients with $\mathrm{AD}$. Indeed, there was a trend for patients with $\mathrm{AD}$ to have less $\mathrm{T}$ cell reactivity to both $\alpha \mathrm{CD} 3 / \mathrm{CD} 28$ and GA, as compared with the adult healthy group $(P=0.09$ and 0.08$)$. Thus, the T cell reactivity we observed for $A \beta$ among healthy elderly subjects and patients with $\mathrm{AD}$ was not related to a generalized increase in $\mathrm{T}$ cell responses of the subjects we tested.
Figure 2

$A \beta T$ cell reactivity is increased in elderly subjects and patients with $A D$. PBMCs were isolated from adult and elderly healthy subjects and patients with $A D$ as described in Methods. $A \beta$-induced proliferation was measured after secondary stimulation in the split-well assay. (a) Percentage of positive wells was calculated for each individual as in Figure 1. (b) Average SIs \pm SEM were calculated for each group on the basis of the average SIs for each individual (sum of positive SIs [each at least 2.5 with a $\Delta$ cpm of $>2,000$ ] divided by the number of positive wells). Two-tailed $P$ values were calculated using the alternate Welch $t$ test, assuming Gaussian populations with unequal SDs.

Epitope mapping and cytokine profile of A $\beta$-reactive T cells. To determine if the $T$ cell response to $A \beta 1-42$ consisted of a response to a single $T$ cell epitope or to multiple epitopes, we generated a panel of 24 short-term $A \beta$-reactive $\mathrm{T}$ cell lines as described in Methods. The specificity and reactivity of each $T$ cell line was initially determined by a dose-dependent proliferation assay using $A \beta 1-42$ and two overlapping $A \beta$ fragments, $A \beta 1-28$ and $A \beta 15-42$. Proliferation of three representative $A \beta 1-42 \mathrm{~T}$ cell lines from three subjects is shown in Figure 3. T cell epitopes were located in the $C$ terminus (AB15-42) in lines 1-3 (Figure $3, \mathrm{a}-\mathrm{C}$ ) and also in the $\mathrm{N}$ terminus $(\mathrm{A} \beta 1-28)$ in line 2 (Figure $3 \mathrm{~b}$ ). We then further investigated the epitope specificity of these three $T$ cell lines using five overlapping peptides within $A \beta 15-42$. As shown in Figure 3 $(\mathrm{d}-\mathrm{f})$, $\mathrm{T}$ cell epitopes were located in $\mathrm{A} \beta 16-30, A \beta 19-33$, and $A \beta 28-42$, respectively. Table 3 summarizes $A \beta$ epitope analyses of T cell lines obtained from healthy subjects ( 6 adults and 12 older individuals) and 6 patients with $A D$. $A \beta$-reactive $T$ cell lines were identified that were specific to $A \beta 16-30, A \beta 19-33$, and $A \beta 28-42$, with the highest frequency of positive $T$ cell lines induced by $A \beta 16-30$. It should be noted that those $T$ cell lines reactive to $A \beta 28-42$ were unreactive to $A \beta 1-40$ (data not shown), suggesting the importance of the two C-terminal residues. HLA restriction was tested in eight

\section{Table 2}

Proliferation of PBMCs stimulated with anti-CD3/CD28 or GA

Adult $\quad$ Elderly $\quad$ AD subjects

$\alpha C D 3 / C D 28 \quad 23,593 \pm 5,810 \quad 15,855 \pm 3,315 \quad 11,377 \pm 3,270$ (mean cPm \pm SEM)

$\begin{array}{lccc}P \text { value (vs. adults) } & (n=10) & (n=15) & (n=13) \\ & & 0.27 & 0.09\end{array}$
GA $\quad 35,342 \pm 7,893 \quad 27,311 \pm 4,781 \quad 19,403 \pm 3,078$ (mean $\mathrm{cPm} \pm \mathrm{SEM}$ )
$P$ value (vs. adults)
$(n=13)$
$(n=30)$
$(n=52)$
$\begin{array}{rl}0.4 & 0.08\end{array}$

For $\alpha C D 3 / C D 28$ stimulation, PBMCs were cultured with $1 \mu \mathrm{g} / \mathrm{ml}$ soluble $\alpha C D 3$ plus $\alpha$ CD28 or cell culture medium alone, pulsed with $\left[{ }^{3} \mathrm{H}\right]$ thymidine on day 2 after stimulation, and incorporation was measured 12 hours later. For GA stimulation, cells were cultured with $50 \mu \mathrm{g} / \mathrm{ml} \mathrm{GA}$ or cell culture medium alone and pulsed with $\left[{ }^{3} \mathrm{H}\right]$ thymidine on day 6 . Mean cpm is the average $\mathrm{cpm}$ for each group; the average cpm for cells with culture medium alone was 825. PBMCs from all subjects stimulated with $\alpha C D 3 / C D 28$ showed proliferation. For GA, $90 \%$ of the subjects (from all groups tested) showed proliferation ( $\mathrm{SI}$ of at least 5). Proliferative responses were calculated from these subjects. Two-tailed $P$ values were calculated for the mean cpm using the alternate Welch $t$ test, assuming Gaussian populations with unequal SDs. 

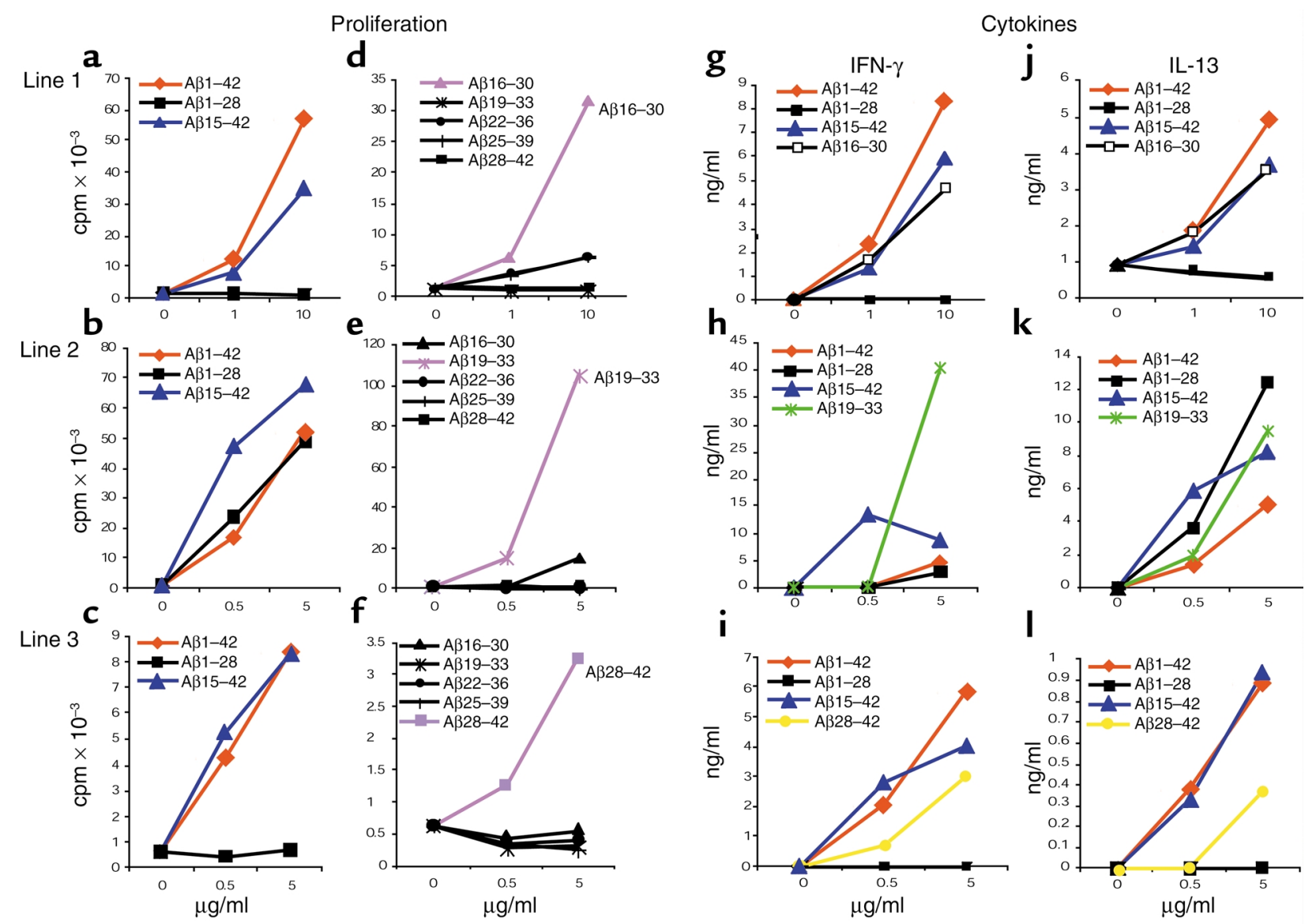

Figure 3

Epitope specificity and cytokine profile of $A \beta$-reactive T cell lines. Split-well assays were performed as described in Methods. To generate A $\beta$ reactive T cell lines, positive wells were restimulated in the presence of irradiated PBMCs and A $\beta$ and then maintained with $10 \mathrm{U} / \mathrm{ml} \mathrm{IL}-2$. To determine $A \beta$ and epitope specificity, T cell lines were stimulated with $A \beta 1-42$ and two overlapping peptides, $A \beta 1-28$ or $A \beta 15-42$, followed by their stimulation with nested peptides of the $A \beta 15-42$ region. To measure $A \beta$-induced cytokine production, supernatants were collected 48 hours after stimulation and examined by ELISA. T cell proliferation of three representative lines is shown: (a-c) induced by $A \beta 1-42$ (a and c) $A \beta 15-42$, and (b) $A \beta 1-28$. T cell proliferation was also induced by (d) $A \beta 16-30$ (e) $A \beta 19-33$, and (f) $A \beta 28-42$. A $\beta$-induced secretion of IFN- $\gamma$ and IL-13 is shown in $\mathbf{g}$ through $\mathbf{I}$.

representative positive subjects bearing different HLA class II alleles. T cell proliferation of these eight A $\beta$-reactive $\mathrm{T}$ cell lines was completely blocked in the presence of the monoclonal anti-HLA-DR antibody LB3.1 but not by antibodies to DP or DQ (data not shown).

To investigate the functional properties of $A \beta$-reactive $\mathrm{T}$ cells, we measured cytokine secretion 48 hours after stimulation with $A \beta 1-42$ or with its various overlapping fragments in the same three representative cell lines used for epitope mapping (Figure 3). T cell lines 1,2, and 3 secreted high amounts of IFN- $\gamma$ and lower amounts of IL-13 when stimulated with $A \beta 1-42$ or C-terminal $A \beta$ fragments between 15 and 42 (Figure 3, $g-1$ ). In the one line that had shown reactivity to the $\mathrm{N}$-terminal $\mathrm{A} \beta 1-28$ peptide (Figure $3 \mathrm{~b}$ ), A $\mathrm{A} 1-28$ also induced the secretion of high levels of IL-13 but not IFN- $\gamma$ (Figure 3 , $h$ and $k$ ). Similar patterns of cytokine secretion were observed in $16 \mathrm{~T}$ cell lines obtained from different subjects (data not shown). Significant levels of IL-4, IL-10, and TGF- $\beta$ could not be detected upon stimulation with any of the $A \beta$ epitopes tested (data not shown).
To further determine the phenotype of $A \beta$-reactive $T$ cells, a representative $T$ cell line also was tested by FACS for Th1 and Th2 cytokine expression. Resting T cells were stimulated with irradiated autologous PBMCs in

Table 3

Distribution of A $\beta$ T cell epitopes in human PBMCs

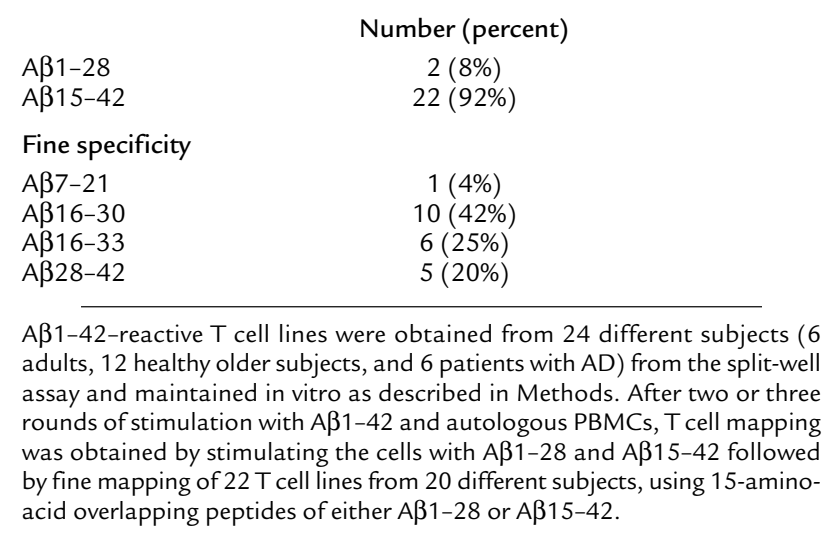




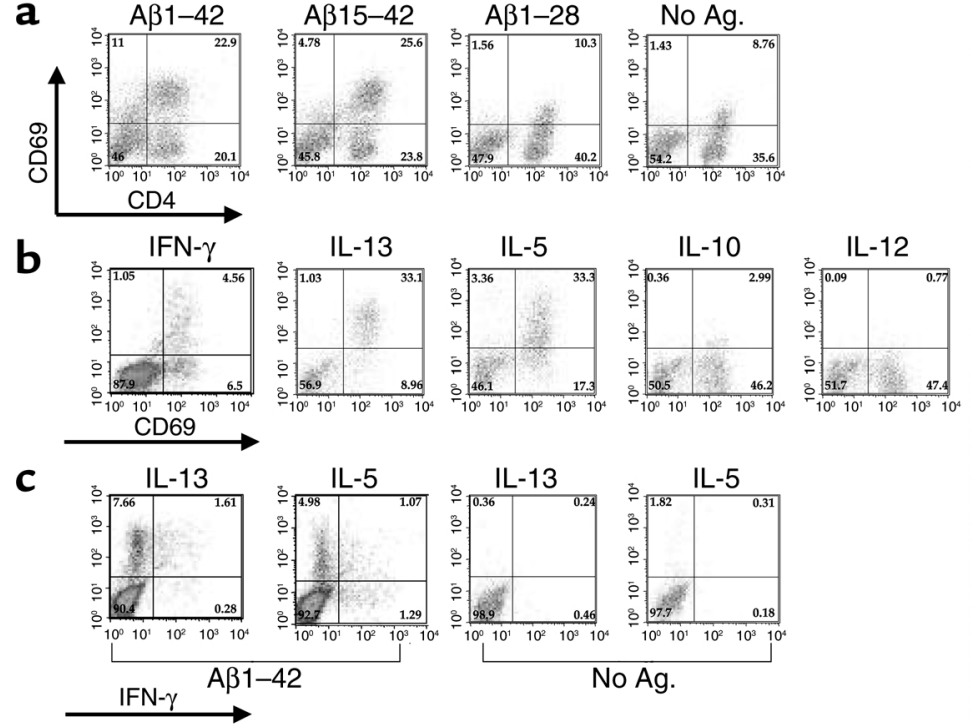

\section{Figure 4}

Activated $A \beta$-reactive T cells exhibit Th1, Th2, and Th0 phenotypes after stimulation with autologous PBMCs and $A \beta$ peptides. $A \beta$-reactive $T$ cells were established from a secondary stimulation assay as described in Methods. Resting cells were cultured with autologous PBMCs alone or stimulated in the presence of $A \beta 1-42, A \beta 15-42$, or $A \beta 1-28$ and harvested after 30 hours. Cells were stained with Cy-chrome-labeled anti-CD4 and FITC-labeled anti-CD69 (a) followed by intracellular staining with phycoerythrin-labeled anti-IFN- $\gamma,-I L-13,-I L-5,-I L-10$, and -IL-12 (b). Cells also were stained with $\mathrm{Cy}$-chrome-labeled anti-CD4 followed by intracellular staining with FITC-labeled anti-IFN- $\gamma$ and phycoerythrin-labeled anti-IL-13 or anti-IL-5 (c). Positive cells were not observed when intracellular staining was performed with isotype controls (data not shown). For (b) and (c), analysis was gated on $\mathrm{CD}^{+}$cells. No Ag., no antigen. the presence of $A \beta 1-42, A \beta 15-42$, or $A \beta 1-28$ and analyzed by FACS 30 hours later. In Figure $4 a$, we measured activation of $\mathrm{CD}^{+} \mathrm{T}$ cells for $\mathrm{A} \beta 1-42, \mathrm{~A} \beta 15-42$, and $A \beta 1-28$ and found increased expression of the CD69 activation marker on $\mathrm{CD}^{+}$cells stimulated with $A \beta 1-42$ and $A \beta 15-42$ but not with $A \beta 1-28$. We then tested the cytokine profile of the activated $\mathrm{T}$ cells as identified by CD69 expression (Figure 4b) and found that cells expressed IL-5 (33.3\%) and IL-13 (33.1\%), with a smaller number of cells expressing IFN- $\gamma(4.56 \%)$ and IL-10 (2.99\%) and very few cells expressing IL-12 $(0.77 \%)$. We further asked whether the cytokine profiles represented primarily $\mathrm{Th} 2$ lineages by testing for the expression of INF- $\gamma$ and IL-13/IL-5 in the same cells. We found that the majority of IL-13- and IL-5-producing cells did not make IFN- $\gamma$, though we could identify a small number of double-positive (IL-13/IL-5 and IFN- $\gamma$ ) cell populations (Figure 4c).

Because the $\mathrm{T}$ cell epitopes were most frequently localized to $A \beta 16-30$, we further mapped this epitope for each of its constituent amino acids by using alanine-substituted peptides in the $\mathrm{T}$ cell proliferation assay (the naturally occurring alanines at positions 21 and 30 were changed to glycines). Substitution of phenylalanine-20, glutamic acid-22, and aspartic acid-23 with alanines blocked or significantly decreased $\mathrm{T}$ cell proliferation at all three concentrations used, whereas substitutions of phenylalanine-19, valine-24, and glycine-29, respectively, had inhibitory effects only at 0.1 or $1 \mu \mathrm{g} / \mathrm{ml}$ (Table 4$)$. Substitution of lysine-16, alanine-21, serine-26, or asparagine-27 increased $\mathrm{T}$ cell proliferation more than twofold (Table 4).

\section{Discussion}

Here, we show, we believe for the first time that circulating $A \beta$-reactive $T$ cells are present in patients with $\mathrm{AD}$ and increase with aging. In addition, we define DRrestricted $T$ cell epitopes reactive with $A \beta$ in humans.
There has been only one previous study in humans that measured $A \beta$-reactive T cells (47). These investigators reported that $\mathrm{A} \beta$-induced $\mathrm{T}$ cell proliferation was similar in young and elderly controls and that such $T$ cells could not be detected in patients with $A D$. The authors postulated that $A \beta$-reactive $T$ cells were anergized in the patients with AD. Our study clearly shows $\mathrm{T}$ cell responses in $\mathrm{AD}$, and this finding may be related to the peptide we studied and the assay system we used. We investigated the more immunogenic peptide $A \beta 1-42$ instead of $A \beta 1-40$ as the stimulating antigen, and our assay system is more sensitive for detection of self-reactive $T$ cells than is the primary

\section{Table 4}

Proliferation of A $\beta 16-30$-specific T cells with alanine/glycine-substituted peptides

\begin{tabular}{lccc}
\hline Peptide $(\mu \mathrm{g} / \mathrm{ml})$ & 0.1 & 1 & 10 \\
A $\beta 16-30$ & 1,648 & 6,780 & 17,339
\end{tabular}

Substituted

$\begin{array}{lcccc}\text { Phe 20 Ala } & 1,288 & 2,239 & 4,216 & \\ \text { Glu 22 Ala } & 1,145 & 840 & 517 & \downarrow \downarrow \downarrow \\ \text { Asp 23 Ala } & 1,145 & 1,685 & 612 & \\ \text { Phe 19 Ala } & 986 & 4,354 & 17,943 & \\ \text { Val 24 Ala } & 944 & 6,160 & 19,869 & \downarrow \\ \text { Gly 29 Ala } & 622 & 3,014 & 14,513 & \\ \text { Leu 17 Ala } & 2,242 & 11,805 & 24,480 & \\ \text { Val 18 Ala } & 7,216 & 17,427 & 26,814 & \uparrow \\ \text { Gly 25 Ala } & 2,426 & 13,763 & 24,979 & \uparrow \\ \text { Lys 28 Ala } & 5,050 & 15,475 & 29,156 & \\ \text { Ala 30 Gly } & 2,123 & 12,027 & 15,395 & \\ \text { Lys 16 Ala } & 5,357 & 22,304 & 36,456 & \uparrow \uparrow \\ \text { Ala 21 Gly } & 12,901 & 29,634 & 36,448 & \uparrow \\ \text { Ser 26 Ala } & 18,808 & 36,287 & 38,335 & \\ \text { Asn 27 Ala } & 23,636 & 36,588 & 34,983 & \\ & & & \end{array}$

$T$ cells specific to $A \beta 16-30$ were stimulated in the presence of alanine/glycine-substituted peptides and autologous PBMCs. T cell proliferation was measured by $\left[{ }^{3} \mathrm{H}\right]$ thymidine incorporation 72 hours after stimulation. Numbers represent the average cpm of each antigen concentration tested (average cpm in the absence of antigen was 911). 
stimulation system used by Trieb et al. (47). These factors may also explain why we found increased reactivity in older subjects, whereas Trieb et al. did not. Our findings were unexpected given that aging is associated with increased susceptibility to infectious agents and defective $\mathrm{T}$ cell priming $(42,43)$, a trend we also observed in our subjects when cells were stimulated with $\alpha \mathrm{CD} 3 / \mathrm{CD} 28$ or GA.

The A $\beta$-reactive $T$ cell response with respect to antigen specificity, HLA class II restriction, and cytokine pattern has not been previously described in humans. CD4 $\mathrm{T}$ cell epitopes were identified primarily in the $A \beta 15-42$ peptide, which is segregated from the dominant $B$ cell epitopes identified in $A \beta 1-15$. Of the several peptides within this region that induced $\mathrm{T}$ cell proliferation, the $\mathrm{A} \beta 16-30$ peptide was the most common epitope. Replacement of amino acids within this epitope with alanine or glycine either completely blocked $\mathrm{T}$ cell proliferation and cytokine production or had an inhibitory effect, suggesting that these residues maintain TCR-MHC interactions. Interestingly, glutamic acid-22 and aspartic acid-23, the replacement of which by alanine blocked $\mathrm{T}$ cell proliferation, are the sites of missense mutations in humans that lead to early onset of AD and/or hereditary cerebral hemorrhage with amyloidosis. We also identified $T$ cell epitopes in A $328-42$. These T cells were specific to $A \beta 1-42$ and could not be stimulated by $A \beta 1-40$, which partially explains the observed higher immunogenicity of $A \beta 1-42$ over $A \beta 1-40$. $T$ cells were infrequently stimulated by the $\mathrm{N}$-terminal region 1-28 residues. We found that monoclonal anti$\mathrm{DR}$ inhibited virtually all $\mathrm{T}$ cell lines tested. The analysis of $A \beta T$ cell epitopes and their restriction to HLA-DR class II further demonstrates that $A \beta$ is processed and presented by APCs in the context of MHC and that $A \beta$-specific T cell proliferation is mediated through MHC-TCR interactions. Thus, $A \beta$ induces adaptive immune responses in the periphery in addition to innate immune responses in the CNS.

It is unknown why $A \beta$-reactive $T$ cells are maintained throughout life and why they increase in the elderly and in patients with $\mathrm{AD}$ in the face of decreasing $T$ cell priming that occurs with aging. $A \beta 1-42$ is a self-antigen, and self-reactive $\mathrm{T}$ cells have been implicated in variety of activities, such as immune regulation, self-maintenance and repair, and autoimmune diseases $(29,30,32,33,48-50)$. In the present study, $\mathrm{A} \beta$-reactive $T$ cells were detected in almost all subjects tested, suggesting that these cells either escape central and peripheral tolerance or are positively selected to maintain the normal $\mathrm{T}$ cell repertoire. The cytokine repertoire of these $\mathrm{T}$ cells was of Th1, Th2, and Th0 phenotypes. It is possible that the activation and expansion of $A \beta$-reactive $T$ cells in the elderly and patients with $A D$ found in our study indicates that $A \beta$ is captured by local APCs in the brain in the context of $A \beta$ deposition, and that these APCs migrate to secondary lymph nodes and induce $\mathrm{T}$ cell activation.
Although $A \beta$ deposition occurs in elderly humans that do not have overt signs of $A D$, there appears to be increased $T$ cell reactivity to $A \beta$ in patients with $A D$, since in contrast to elderly subjects, all patients with $A D$ tested had some $A \beta$ reactivity. Such reactivity could reflect an endogenous reaction to $A \beta$ deposition in the brain in the context of the local innate immune response that occurs in $\mathrm{AD}$.

In a recent $A \beta$ vaccination trial, some patients with AD developed brain inflammation, hypothesized to be due to induced $T$ cell responses (24). On the basis of our findings of endogenous reactivity to $A \beta$ in patients with $A D$, the use of a full-length $A \beta$ peptide and a Th1 adjuvant (QS21) might be expected, in retrospect, to lead to $\mathrm{T}$ cell-mediated CNS inflammatory effects, particularly in patients with $\mathrm{AD}$ having a preexisting high frequency of $A \beta$-reactive T cells. Of note, increased $T$ cell reactivity to $A \beta$ was not observed preclinically in APP transgenic mice, perhaps because of their very high levels of peripheral $A \beta$ and the consequent induction of $\mathrm{T}$ cell tolerance (51). However, it has recently been shown that immunization of naive C57BL6 mice with A $\beta 1-42$ emulsified in CFA and injected with pertussis toxin resulted in a mild form of experimental autoimmune encephalomyelitis (52). In addition, the encephalitis may also be due to antigen spreading and expansion of $\mathrm{T}$ cells specific to CNS myelin antigens such as myelin basic protein and proteolipid protein. Furthermore CNS peptides associated with neurodegeneration were immunogenic in Lewis rats, and among these peptides was $\beta$-synuclein, which was found to be expressed in myelin, induced acute paralytic encephalomyelitis (53).

$\mathrm{T}$ cells may have regulatory properties as well as causing harmful autoimmune responses. We found that $A \beta$ administered intranasally to APP transgenic mice induced anti-A $\beta$ antibodies and partial clearance of $A \beta$ plaques, accompanied by infiltration into the CNS of small numbers of mononuclear cells expressing the anti-inflammatory cytokines IL-4, IL-10, and TGF- $\beta$ (17). It was recently shown that overexpression of TGF- $\beta$ in the CNS of APP transgenic mice resulted in a significant reduction of $A \beta$ plaque burden by promoting microglial clearance of the peptide (54). Since almost all human $\mathrm{A} \beta$-reactive $\mathrm{T}$ cell lines we studied also showed a Th2 phenotype, it is possible that mucosal immunization could boost this lineage and thus enhance clearance of $A \beta$ by both stimulating $A \beta$ antibody production $(24,55)$ and modulating microglial activation at sites of $A \beta$ plaques, with a minimal risk of harmful $\mathrm{T}$ cell responses in the CNS.

In summary, in addition to the clear relevance of our findings of intrinsic $A \beta T$ cell reactivity for vaccination strategies in $A D$, the increased responses to $A \beta$ we observed with age may be an important link to physiological immune responses to $A \beta$ that may have either beneficial or harmful effects for the host. Given that $\mathrm{T}$ cell immunity tends to decrease with age, the increased reactivity to $A \beta$ we observed may represent an unusual 
immunologic response that could provide insights into the aging process and its relationship to $A \beta$.

\section{Acknowledgments}

We thank Dorene Rentz for clinical support, Lara O'Brien for assistance with clinic coordination, and David Hafler for advice related to T cell assays. This work was supported by the NIH, the Foundation for Neurologic Diseases and The Alzheimer's Association.

1. Price, D.L., and Sisodia, S.S. 1998. Mutant genes in familial Alzheimer's disease and transgenic models. Annu. Rev. Neurosci. 21:479-505.

2. Selkoe, D.J. 2001. Alzheimer's disease: genes, proteins, and therapy. Physiol. Rev. 81:741-766.

3. Urbanc, B., et al. 2002. Neurotoxic effects of thioflavin S-positive amyloid deposits in transgenic mice and Alzheimer's disease. Proc. Natl. Acad. Sci. U. S. A. 99:13990-13995.

4. Jarrett, J.T., and Lansbury, P.T., Jr. 1993. Seeding "one-dimensional crystallization" of amyloid: a pathogenic mechanism in Alzheimer's disease and scrapie? Cell. 73:1055-1058.

5. McGeer, E.G., and McGeer, P.L. 1998. The importance of inflammatory mechanisms in Alzheimer disease. Exp. Gerontol. 33:371-378.

6. Cooper, N.R., Kalaria, R.N., McGeer, P.L., and Rogers, J. 2000. Key issues in Alzheimer's disease inflammation. Neurobiol. Aging. 21:451-453.

7. Akiyama, H., et al. 2000. Inflammation and Alzheimer's disease. Neurobiol. Aging. 21:383-421.

8. Togo, T., et al. 2002. Occurrence of T cells in the brain of Alzheimer's disease and other neurological diseases. J. Neuroimmunol. 124:83-92.

9. Lue, L.F., et al. 2001. Inflammatory repertoire of Alzheimer's disease and nondemented elderly microglia in vitro. Glia. 35:72-79.

10. Haas, J., Storch-Hagenlocher, B., Biessmann, A., and Wildemann, B. 2002. Inducible nitric oxide synthase and argininosuccinate synthetase: coinduction in brain tissue of patients with Alzheimer's dementia and following stimulation with $\beta$-amyloid $1-42$ in vitro. Neurosci. Lett. 322:121-125.

11. Heneka, M.T., et al. 2002. Noradrenergic depletion potentiates $\beta$-amyloidinduced cortical inflammation: implications for Alzheimer's disease. J. Neurosci. 22:2434-2442.

12. Smits, H.A., et al. 2002. Amyloid-B-induced chemokine production in primary human macrophages and astrocytes. J. Neuroimmunol. 127:160-168.

13. Wyss-Coray, T., et al. 2003. Adult mouse astrocytes degrade amyloid- $\beta$ in vitro and in situ. Nat. Med. 9:453-457.

14. Schenk, D., et al. 1999. Immunization with amyloid- $\beta$ attenuates Alzheimer-disease-like pathology in the PDAPP mouse. Nature. 400:173-177.

15. Morgan, D., et al. 2000. A $\beta$ peptide vaccination prevents memory loss in an animal model of Alzheimer's disease. Nature. 408:982-985.

16. Janus, C., et al. 2000. A $\beta$ peptide immunization reduces behavioural impairment and plaques in a model of Alzheimer's disease. Nature. 408:979-982.

17. Weiner, H.L., et al. 2000. Nasal administration of amyloid- $\beta$ peptide decreases cerebral amyloid burden in a mouse model of Alzheimer's disease. Ann. Neurol. 48:567-579.

18. Lemere, C.A., et al. 2000. Nasal A $\beta$ treatment induces anti-A $\beta$ antibody production and decreases cerebral amyloid burden in PD-APP mice. Ann. N. Y. Acad. Sci. 920:328-331.

19. Bard, F., et al. 2000. Peripherally administered antibodies against amyloid $\beta$-peptide enter the central nervous system and reduce pathology in a mouse model of Alzheimer disease. Nat. Med. 6:916-919.

20. Dodart, J.C., et al. 2002. Immunization reverses memory deficits without reducing brain A $\beta$ burden in Alzheimer's disease model. Nat. Neurosci. 5:452-457.

21. Schenk, D. 2003. Immunization against Alzheimer's disease and other neurodegenerative disorders. D. Selkoe and Y. Christen, editors. Springer-Verlag New York Inc. New York, New York, USA. 130 pp.

22. Hock, C., et al. 2002. Generation of antibodies specific for $\beta$-amyloid by vaccination of patients with Alzheimer disease. Nat. Med. 8:1270-1275.

23. Pfeifer, M., et al. 2002. Cerebral hemorrhage after passive anti-A $\beta$ immunotherapy. Science. 298:1379.

24. Nicoll, J.A., et al. 2003. Neuropathology of human Alzheimer disease after immunization with amyloid- $\beta$ peptide: a case report. Nat. Med. 9:448-452.

25. Gammon, G., and Sercarz, E. 1989. How some T cells escape tolerance induction. Nature. 342:183-185.

26. Peterson, D.A., DiPaolo, R.J., Kanagawa, O., and Unanue, E.R. 1999. Quantitative analysis of the $\mathrm{T}$ cell repertoire that escapes negative selection. Immunity. 11:453-462.

27. Janeway, C.A., Jr. 1999. T cell development: a role for self-peptides in positive selection. Curr. Biol. 9:R342-R345.

28. Cohen, I.R. 1992. The cognitive principle challenges clonal selection. Immunol. Today. 13:441-444

29. Schwartz, M., and Cohen, I.R. 2000. Autoimmunity can benefit self-maintenance. Immunol. Today. 21:265-268.

30. Kitani, A., Chua, K., Nakamura, K., and Strober, W. 2000. Activated selfMHC-reactive T cells have the cytokine phenotype of Th3/T regulatory cell 1 T cells. J. Immunol. 165:691-702.

31. Cohen, I.R. 2001. Antigenic mimicry, clonal selection and autoimmunity. J. Autoimmun. 16:337-340.

32. Apostolou, I., Sarukhan, A., Klein, L., and von Boehmer, H. 2002. Origin of regulatory $\mathrm{T}$ cells with known specificity for antigen. Nat. Immunol. 3:756-763.

33. Kawahata, K., et al. 2002. Generation of $\mathrm{CD} 4{ }^{+} \mathrm{CD} 25^{+}$regulatory T cells from autoreactive $T$ cells simultaneously with their negative selection in the thymus and from nonautoreactive T cells by endogenous TCR expression. J. Immunol. 168:4399-4405.

34. Wekerle, H. 1993. T cell autoimmunity in the central nervous system. Intervirology. 35:95-100.

35. Becher, B., Prat, A., and Antel, J.P. 2000. Brain-immune connection: immuno-regulatory properties of CNS-resident cells. Glia. 29:293-304.

36. Hickey, W.F. 2001. Basic principles of immunological surveillance of the normal central nervous system. Glia. 36:118-124.

37. Gaskin, F., Finley, J., Fang, Q., Xu, S., and Fu, S.M. 1993. Human antibodies reactive with $\beta$-amyloid protein in Alzheimer's disease.J. Exp. Med. 177:1181-1186

38. Lomakin, A., Benedek, G.B., and Teplow, D.B. 1999. Monitoring protein assembly using quasielastic light scattering spectroscopy. Methods Enzymol. 309:429-459.

39. McKhann, G., et al. 1984. Clinical diagnosis of Alzheimer's disease: report of the NINCDS-ADRDA Work Group under the auspices of Department of Health and Human Services Task Force on Alzheimer's Disease. Newrology. 34:939-944.

40. Folstein, M.F., Folstein, S.E., and McHugh, P.R. 1975. "Mini-mental state". A practical method for grading the cognitive state of patients for the clinician. J. Psychiatr. Res. 12:189-198.

41. Fukaura, H., et al. 1996. Induction of circulating myelin basic protein and proteolipid protein-specific transforming growth factor- $\beta 1$-secreting Th3 $\mathrm{T}$ cells by oral administration of myelin in multiple sclerosis patients. J. Clin. Invest. 98:70-77.

42. Linton, P.J., Haynes, L., Klinman, N.R., and Swain, S.L. 1996. Antigenindependent changes in naive CD4 T cells with aging. J. Exp. Med. 184:1891-1900

43. Bansal-Pakala, P., and Croft, M. 2002. Defective T cell priming associated with aging can be rescued by signaling through 4-1BB (CD137). J. Immunol. 169:5005-5009.

44. Grubeck-Loebenstein, B., and Wick, G. 2002. The aging of the immune system. Adv. Immunol. 80:243-284.

45. Teitelbaum, D., Meshorer, A., Hirshfeld, T., Arnon, R., and Sela, M. 1971. Suppression of experimental allergic encephalomyelitis by a synthetic polypeptide. Eur.J. Immunol. 1:242-248.

46. Duda, P.W., Krieger, J.I., Schmied, M.C., Balentine, C., and Hafler, D.A. 2000. Human and murine CD4 T cell reactivity to a complex antigen: recognition of the synthetic random polypeptide glatiramer acetate. J. Immunol. 165:7300-7307.

47. Trieb, K., Ransmayr, G., Sgonc, R., Lassmann, H., and Grubeck-Loebenstein, B. 1996. APP peptides stimulate lymphocyte proliferation in normals, but not in patients with Alzheimer's disease. Neurobiol. Aging. 17:541-547.

48. Cohen, I.R., and Schwartz, M. 1999. Autoimmune maintenance and neuroprotection of the central nervous system. J. Neuroimmunol. 100:111-114.

49. Weiner, H.L. 2001. Oral tolerance: immune mechanisms and the generation of Th3-type TGF- $\beta$-secreting regulatory cells. Microbes Infect. 3:947-954.

50. Scheinecker, C., McHugh, R., Shevach, E.M., and Germain, R.N. 2002. Constitutive presentation of a natural tissue autoantigen exclusively by dendritic cells in the draining lymph node. J. Exp. Med. 196:1079-1090.

51. Monsonego, A., Maron, R., Zota, V., Selkoe, D.J., and Weiner, H.L. 2001. Immune hyporesponsiveness to amyloid $\beta$-peptide in amyloid precursor protein transgenic mice: implications for the pathogenesis and treatment of Alzheimer's disease. Proc. Natl. Acad. Sci. U. S. A. 98:10273-10278.

52. Furlan, R., et al. 2003. Vaccination with amyloid- $\beta$ peptide induces autoimmune encephalomyelitis in C57/BL6 mice. Brain. 126:285-291.

53. Mor, F., Quintana, F., Mimran, A., and Cohen, I.R. 2003. Autoimmune encephalomyelitis and uveitis induced by T cell immunity to self $\beta$-synuclein. J. Immunol. 170:628-634.

54 . Wyss-Coray, T., et al. 2001 . TGF- $\beta 1$ promotes microglial amyloid- $\beta$ clearance and reduces plaque burden in transgenic mice. Nat. Med. 7:612-618.

55. Hock, C., et al. 2003. Antibodies against beta-amyloid slow cognitive decline in Alzheimer's disease. Neuron. 38:547-554. 